\title{
Preliminary Examination of Polymorphisms of GSTM1, GSTT1, and GSTZ1 in Relation to Semen Quality
}

\author{
Andrew F. Olshan ${ }^{a},{ }^{,}$, Thomas J. Luben ${ }^{a, 1}$, Nancy M. Hanleyd, Sally D. Perreault ${ }^{c}$, Ronna L. \\ Chan $^{a}$, Amy H. Herring ${ }^{b}$, Patricia V. Basta ${ }^{a}$, and David M. DeMarini ${ }^{d}$ \\ aDepartment of Epidemiology, University of North Carolina Gillings School of Global Public \\ Health, Chapel Hill, NC 27599, USA \\ bDepartment of Biostatistics, University of North Carolina Gillings School of Global Public Health, \\ Chapel Hill, NC 27599, USA \\ 'Office of Research and Development, U.S. Environmental Protection Agency, Research Triangle \\ Park, NC 27711, USA \\ dIntegrated Systems Toxicology Division, US Environmental Protection Agency, Research \\ Triangle Park, NC 27711, USA
}

\begin{abstract}
Background-Environmental, lifestyle, and occupational exposures on semen quality have been investigated in epidemiological studies with inconsistent results. Genetic factors involved in toxicant activation and detoxification have been examined in relation to the risk of outcomes such as cancer, cardiovascular, and neurologic disorders. However, the effect of common genetic variants in the metabolism of toxicants on semen quality parameters has rarely been evaluated. In this analysis, we evaluated functional SNPs of three genes of the glutathione-S-transferase (GSTM1, GSTT1, GSTZ1) enzyme family.
\end{abstract}

Methods-Participants were 228 presumed fertile men recruited as part of a community-based study. Semen outcome data from this study included total sperm count and concentration, sperm morphology, and sperm DNA integrity and chromatin maturity. DNA was obtained from 162 men from a mouth-rinse sample and genotyped for the presence of GSTT1-1 and GSTM1-1 null genotypes and the GSTZ1 SNPs at positions 94 (rs3177427) and 124 (rs3177429). We used multivariable linear regression to assess the relationship between each genotype and sperm outcomes.

\footnotetext{
(C) 2010 Elsevier B.V. All rights reserved.

*Corresponding Author: Department of Epidemiology, CB \#7435, University of North Carolina School of Public Health, Chapel Hill, North Carolina 27599 Phone: 919-966-7419 Fax: 919-966-2089 andy_olshan@unc.edu.

${ }^{1}$ Present Address: Office of Research and Development, National Center for Environmental Assessment, US Environmental

Protection Agency, Research Triangle Park, NC, USA

Conflict of interest

The authors declare they have no conflict of interest or competing financial interests.

Disclaimer

This document has been reviewed by the National Health and Evironmental Effects Research Laboratory of the U.S. EPA and approved for publication. Approval does not signify that the contents reflects the views of the Agency, nor does mention of trade names or commercial products constitute endorsement or recommendation for use.

Publisher's Disclaimer: This is a PDF file of an unedited manuscript that has been accepted for publication. As a service to our customers we are providing this early version of the manuscript. The manuscript will undergo copyediting, typesetting, and review of the resulting proof before it is published in its final citable form. Please note that during the production process errors may be discovered which could affect the content, and all legal disclaimers that apply to the journal pertain.
} 
Results-Overall, our results did not reveal a consistent pattern between GSTM1 and GSTZ genotypes and increased occurrence of adverse sperm outcomes. However, the GSTT1 non-null genotype yielded the coefficients with the largest magnitude for sperm count and sperm concentration $(\beta=-0.528,95 \% \mathrm{CI}-1.238-0.199$ and $\beta=-0.353,95 \% \mathrm{CI}-0.708-0.001$, respectively), suggesting that it might be adverse.

Conclusions-These results indicate that common polymorphisms in GST genes do not negatively impact sperm parameters in healthy men with good semen quality. Contrary to expectations, the GSTT1 non-null genotype was associated with reduced sperm concentration and count in semen. Further study with a larger study size and inclusion of gene-exposure interactions is warranted.

\section{Keywords}

epidemiology; human; male; reproduction; semen; sperm count; genetic; polymorphism; Glutathione Transferase

\section{Introduction}

The potential impacts of environmental, lifestyle, and occupational exposures on semen quality have been examined in various epidemiological studies [1-9] Some studies have been limited to routine semen outcomes such as sperm counts, motility, and morphology, whereas more recent studies have also included measures of sperm DNA, and chromosome or chromatin integrity [10-14]. Although mechanistic pathways are rarely examined in these studies, it is suspected that the exposure effects may be mediated through inherited genetic factors involved in toxicant activation and detoxification.

An important enzyme family involved in the detoxification of reactive intermediates is glutathione-S-transferase (GST). These enzymes are involved in the conjugation of reactive intermediates with glutathione, facilitating excretion, and are generally protective. However, GST theta has also been shown to activate some substrates to reactive intermediates that are mutagenic. For example GST theta (GSTT1-1) activates the brominated trihalomethanes, which are disinfection byproducts present in drinking water [15].

Several GST enzymes are encoded by genes with known functional polymorphisms. For example, deletions in GSTM1 (coding for GST mu1) and GSTT1 (coding for GST theta1) are relatively common in human populations [16]. Homozygous deletions GSTMI*0 and $G S T T 1^{*} 0$ result in a lack of enzyme activity [17-18]. These polymorphisms have been associated with an increased risk of cancer, heart disease, and adverse reproductive outcomes [19-21]. In addition, GSTMI $* 0$ has been examined in relation to semen quality and infertility in a small number of studies [22-24]. GSTZ (coding for GST zeta) catalyzes the glutathione-dependent biotransformation of $\alpha$-haloacetic acids, including dichloroacetic acid (DCA), a disinfection byproduct, to glyoxylic acid [25]. Promoter and non-synonymous exonic SNPs of the human GSTZ have been identified [26-28], resulting in five known isoforms of the GSTZ1 protein. These protein isoforms are a result of four nonsynonomous SNPs (located at the nucleotides positions 23, 94, 124, and 245 corresponding to amino acids $8,32,42$, and 82). Isoform GSTZ1A contains a Lys rather than a Glu at amino acid 32 and an Arg rather than a Gly at amino acid 42. This isoform has been shown to have increased activity for certain alpha-haloacid substrates, due primarily to an increase in the s resistance to inactivation by dichloroacetate (DCA) [26-27].

We examined the relationship between these common polymorphisms of GSTM1, GSTT1, and GSTZI and semen quality, including sperm count, sperm concentration, sperm morphology, and sperm chromatin integrity, among a cohort of presumed fertile men. 


\section{Materials and Methods}

\subsection{Study population}

Genotype data were obtained on a subgroup of men who participated in the "Healthy Men

Study" (HMS), a study of drinking water disinfection by-products and semen quality. As has been described previously [14, 29], HMS identified male partners of women who participated in a prospective study of drinking water disinfection byproducts and spontaneous abortion and other pregnancy outcomes, the "Right From the Start" study [3031], conducted in three sites (Raleigh, NC; Memphis, TN; and Galveston, TX). A total of 228 men were included in the primary HMS analysis [14].

\subsection{Semen collection and processing}

The semen collection and analyses methods have been described in detail elsewhere [14, 29]. Briefly, participants were asked to provide a single semen sample using a special kit designed to allow the man to collect a semen specimen in the privacy of his own home and at a time convenient to him [32]. All samples were packaged with cold packs (necessary to maintain sample stability for the sperm chromatin structure assay, SCSA) and shipped by overnight courier to a single laboratory at the U.S. EPA. Immediately upon receipt, semen volume was measured, and aliquots were removed for determination of sperm concentration by IVOS-IDENT (Hamilton Thorne Research, Beverly, MA.) [33], from which total sperm count was calculated. Additional aliquots were taken to prepare smears that were air-dried and stored for later analyses of sperm morphology [34]. Sperm motility, which declines over time and, therefore, is not a reliable measure for shipped semen, was not included in the statistical analysis. Additional aliquots $(0.1 \mathrm{ml})$ were frozen and stored at $-70^{\circ} \mathrm{C}$ for later analysis of chromatin integrity by SCSA [35], and for chromatin immaturity (protamine deficiency indicated by chromomycin A3 (CMA) staining [36].

\subsection{Sperm outcome measures}

In this analysis we focused on the following sperm outcomes: sperm count (million/sample) and sperm concentration (million/ml semen), sperm morphology (\% normal sperm) including its components (percent of sperm cells with abnormal head, percent of sperm cells with abnormal midsection, percent of sperm cells with abnormal tails, and percent of sperm cells with abnormal cytoplasmic drop), percent sperm with DNA fragmentation, indicative of DNA damage, according to SCSA (\%DFI), and \% sperm with immature chromatin according to CMA staining.

\subsection{Mouth-rinse collection}

The present study of genetic polymorphisms was added to the primary HMS project. We recontacted and recruited approximately 230 male participants in all three study sites who had successfully completed all of the parent HMS study activities (i.e., provided a signed consent form, completed telephone interview, and provided a donation of semen specimen according to study protocol). Men who had declined originally to participate in HMS, dropped out, or failed to complete all study activities were not re-contacted. Once an HMS participant agreed to participate in the polymorphism study, we scheduled the mailing of a mouth-rinse kit for buccal cell collection. At the end of recruitment and follow-up period, 227 recruitment letters were mailed, 188 agreed to participate, and 162 returned their specimen collection kits (response frequency: 162/188 $=86.2 \%$ ). DNA was isolated from buccal cells by a standard high salt extraction method using Puregene chemistries (Qiagen, Valencia CA). 


\subsection{Sample processing and genotyping}

A multiplex PCR was performed to analyze for the presence of GSTT1-1 and GSTM1-1 [37], and an additional method [38] was also used to confirm the GSTT1-1 genotype. Genotyping of the GSTZ1 SNPs at positions 94 (rs3177427) and 124 (rs3177429) was performed on an Applied Biosystems (ABI) 7300 machine using ABI Pre-Designed/Validated TaqMan MGB probes and primers and TaqMan Universal Master Mix (no UNG) and analyzed using ABI software version 2.2. All samples were run in duplicate, and concordance between duplicates was $100 \%$. Out of 162 samples, two could not be genotyped for rs3177427.

\subsection{Statistical analyses}

Several of the outcome variables were transformed to better approximate the normality assumption of the linear model. Specifically, a natural log transformation was applied to the sperm count and concentration variables, and an arc sine transformation was applied to the percent normal sperm cells, percent of sperm cells with abnormal head, percent of sperm cells with abnormal midsection, percent of sperm cells with abnormal tails, and percent of sperm cells with abnormal cytoplasmic drop. Linear regression was used to assess the association between each genotype variable and each outcome, adjusted for potential confounders (race/ethnicity, age, and study site). Abstinence interval was examined as a potential confounder but was not significant in the model. Although abstinence is related to the semen quality measures, it is not associated with genotype. Thus, it would not be expected to confound the relationship of interest. We also examined history of cigarette smoking (ever/never, amount, and ever/never is the 90- days before semen sample collection), but its adjustment did not materially alter the regression coefficients. For interpretability, each of the outcome variables was standardized (after statistical transformation, if applied) such that the standard deviation and the variance were equal to one. Thus each beta coefficient provides an estimate of effect in terms of a change in standard deviations of the transformed response variable. We used SAS version 9.1 software (Cary, NC) to perform all analyses.

\section{Results}

The subjects included in the genetic analyses were primarily from Memphis and Raleigh sites (69 and 67, respectively), with only 26 (16\%) coming from the Galveston site (Table 1). The majority of the men was white, non-Hispanic, between 25 and 34 years old, and had a college degree. Over $80 \%$ of the subjects had household incomes of $\$ 40,000$ or more. About one-third of the subjects reported smoking cigarettes. Subjects who agreed to participate in the genetic analyses were more likely to be white, non-Hispanic, better educated, and to smoke cigarettes when compared to all of the men eligible for the original HMS study.

Table 2 presents the self-reported racial and ethnic characteristics of the final participants stratified by genotype. None of the participants with the GSTMI $* 0$ null genotype were Black or Hispanic. Similarly, the $G S T T 1 * 0$ null genotype was found only among nonHispanic participants. None of the heterozygous variant carriers (GA) of the GSTZ1 SNP 124 were Hispanic. Furthermore, the only carriers of the homozygous variant (AA) of the GSTZ1 SNP 94 and SNP 124 were white.

Although this study was motivated by reported impacts of GST polymorphisms and metabolism of disinfectant byproducts (mainly brominated trihalomethanes and haloacetic acids), the number of participants was not sufficient to examine interactions with disinfectant byproduct exposures. Therefore, we examined potential associations between the null genotypes and semen outcomes. Overall, our results did not reveal a consistent 
pattern between GSTM1 and GSTZ genotypes and increased occurrence of adverse sperm outcomes. We present the beta coefficients for genotype from the multivariable linear regression, adjusted for age, race, and study site in Table 3 . When interpreting the information in Table 3, it is important to note that negative beta coefficients indicate an association between a variant genotype and poorer outcomes for sperm count, sperm concentration and percent normal sperm morphology, whereas positive beta coefficients indicate an association between a variant genotype and elevated DNA/chromatin abnormalities (i.e., percent DFI or CMA).

The comparisons of GSTT1 genotype with sperm count and sperm concentration yielded the coefficients with the largest magnitude $(\beta=-0.528,95 \% \mathrm{CI}-1.238-0.199$ and $\beta=-0.353$, $95 \% \mathrm{CI}-0.708-0.001$, respectively). This indicated that, on average, men with the $G S T T 1 * 1$ non-null genotype (normal levels of the enzyme) would have a sperm count one-half of a standard deviation lower on the log scale and sperm concentration one-third of a standard deviation lower on the log scale than men with the $G S T T 1 * 0$ (null) genotype. None of the other comparisons yielded coefficients with higher magnitudes or confidence intervals approaching statistical significance.

\section{Discussion}

Individuals often respond differentially to environmental exposures, with some exhibiting adverse effects and others not. Variations within genes, including single nucleotide polymorphisms and other small mutations, may account for this differential susceptibility. One of the best studied examples is the family of GSTs, which are multifunctional proteins involved in detoxification of electrophonic xenobiotics [39] and that may act as intracellular transport proteins [40].

The potential importance of GSTs in male reproductive function is implicated by their presence in the testis and seminiferous tubule fluid [41] and on sperm [42], where they are thought to play detoxification and protective roles. The chemoprotective functions of GSTs [reviewed by 43-44] would be expected to be especially important in the testes where GSTs could attenuate the toxicity of reactive oxygen species (ROS) to Leydig cells, Sertoli cells, and germ cells [45]. Developing and maturing sperm are also highly sensitive to lipid peroxidative and DNA damage associated with ROS which, in turn, is associated with male infertility [46-47].

Recently, GST polymorphisms have been examined for their potential to influence susceptibility to damage from reproductive toxicants, including those that impact spermatogenesis and/or damage sperm DNA. The GSTM ${ }^{*} 0$ (null) genotype has been found to lower seminal plasma antioxidant capacity, which may result in sperm dysfunction for patients with varicocele [48]. Also GSSTI*I men (non-null) showed improvement in semen quality after varicocoelectomy (and more so if they were also $G S T M 1 * 1$ ), whereas men with the null genotype did not [49]. Recently, Messaros et al. [50] reported significantly lower semen quality (numbers, morphology and motility) in men exposed to the organochlorines DDE and DDT, who were also null for GSTT1 (and carried a polymorphism for CYP1A1) than similarly exposed men who carried the common allele for these genes.

These studies suggest that polymorphisms are related to response to toxicants, they may play a more important protective role in infertile than fertile men, and that the ability to respond to oxidative stress depends on multiple genes and enzymes. Two related environmental epidemiology studies found an association between exposure to episodically high levels of industrial air pollution and increased DNA damage in sperm as measured by SCSA [11, 51] A companion study demonstrated a gene-environment interaction whereby men with the 
homozygous deletion of GSTM1 exhibited an increased susceptibility to the risk of sperm DNA damage (measured with SCSA) associated with this exposure [52].

Here we examined several common genetic variants in three GST genes. The functions of two of these variants have been well characterized. As described above, several previous studies have suggested that the GSTM1 deletion polymorphism may limit antioxidant potential in reproductive tissue and fluids, thereby increasing oxidative stress and associated adverse effects on semen quality and sperm DNA damage. However, our community-based study of fertile men did not indicate an association, in the absence of an identified exposure, of the GSTM1 deletion polymorphism or GSTZ1 SNPs with any of the semen quality measures that we examined, nor with markers of sperm DNA damage. We cannot rule out potential associations with altered sperm motility which is sensitive to oxidative damage, because we were not able to assess sperm motility in our shipped samples. However, in the air pollution study cited above [52] only indicators of DNA damage were associated with high exposures to air pollution in men with GSTM1 deletions whereas sperm motility and motion parameters were not.

GSTZ1 plays a role in the metabolism of $\alpha$-haloacetic acids, including several measured in drinking water [25]. We evaluated two GSTZ1 SNPs that have been shown to have functional consequences; however, these variants are rare. For example, only 1 man was a double homozygote for the two GSTZ1 SNPs. Contrary to expectations, the GSTT1 non-null genotype was associated with lower sperm concentration and count in semen. Our expectation was that the null genotype would confer less detoxification capacity and, thereby, increase the risk of poorer semen quality. We speculate that this apparently contradictory observation may be explained by the ability of the GSTT1 enzyme to operate through an alternate pathway whereby compounds may be activated to reactive intermediates, thus increasing stress, but this was not tested empirically. However, we cannot rule out chance as an explanation for these findings.

This study has several strengths, including that it is a community-based sample of men who are presumed fertile by means of their recruitment through a pregnancy cohort study. This recruitment strategy resulted in a selected population of men who do not have serious underlying reproductive pathologies that could confound the analysis. Indeed, our population had excellent semen quality compared with unselected cohorts or infertility clinics reported in the literature. Also, we were able to examine multiple indicators of semen quality (with the exception of sperm motility) and DNA damage, and we considered data on multiple covariates. In the present analysis, the main effect estimates of most SNPs were relatively precise. This study was not large enough to estimate precisely the interaction between genotype and drinking water disinfectant byproduct exposures. However, disinfectant byproduct exposure was not consistently related to decreased sperm quality in the previous HMS analysis [14].

These results suggest that common polymorphisms in GST genes do not negatively impact sperm parameters in healthy men with good semen quality and in the absence of exogenous oxidative stressors. The lack of association of decreased sperm measures with any single genotype examined here is consistent with the result of Messaros et al. [50] in which the presence of $G S T M I * 0$ or $G S T T 1 * 0$ alone was not associated with decreased semen quality. To the contrary, the $G S T T 1 * 0$ genotype is possibly protective in comparison with $G S T T 1 * 1$. Future studies should incorporate a larger study size and include exposures with toxicity pathways related to the enzymes in question in order to evaluate gene-exposure interactions. 


\title{
Acknowledgments
}

\author{
Grant Information
}

We wish to acknowledge J. Smith and Y. Shen for programming and statistical contributions to this project. We also gratefully acknowledge the assistance of Lyle Lansdell with the study conduct. This research was supported in part by grants from the US Environmental Protection Agency (R-82932701), National Institute of Environmental Health Sciences (P30ES10126, T32ES007018), and American Water Works Association Research Foundation (CR825625-01, CR827268-01, CR828216-01).

\section{Abbreviations}

$\begin{array}{ll}\text { CMA } & \text { chromomycin A3 } \\ \text { DCA } & \text { dichloroacetic acid } \\ \text { DDE } & \text { organochlorine } \\ \text { DDT } & \text { organochlorine } \\ \text { GA } & \text { heterozygous variant carriers } \\ \text { GST } & \text { glutathione-S-transferase } \\ \text { GSTM1 } & \text { coding for GST mu1 } \\ \text { GSTT1 } & \text { coding for GST theta1 } \\ \text { GSTZ } & \text { coding for GST zeta } \\ \text { GSTZ1 } & \text { protein } \\ \text { GSTZ1A } & \text { isoform protein } \\ \text { HMS } & \text { Healthy Men Study } \\ \text { ROS } & \text { reactive oxygen species } \\ \text { SCSA } & \text { sperm chromatin structure assay }\end{array}$

\section{References}

1. Sokol RZ, Kraft P, Fowler IA, Mamet R, Kim E, Berhane KT. Exposure to environmental ozone alters semen quality. Environ Health Perspect. 2006; 114:360-365. [PubMed: 16507458]

2. Pant N, Shukla MM, Kumar Patel DD, Shukla YY, Mathur NN, Kumar Gupta YY, Saxena DK. Correlation of phthalate exposures with semen quality. Toxicol Appl Pharmacol. 2008; 231:112116. [PubMed: 18513777]

3. Duty SM, Silva MJ, Barr DB, Brock JW, Ryan L, Chen Z, Herrick RF, Christiani DC, Hauser R. Phthalate exposure and human semen parameters. Epidemiology. 2003; 14:269-277. [PubMed: 12859026]

4. Fenster L, Waller K, Windham G, Henneman T, Anderson M, Mendola P, Overstreet JW, Swan SH. Trihalomehtane levels in home tap water and semen quality. Epidemiology. 2003; 14:650-658. [PubMed: 14569179]

5. Swan SH. Do environmental agents affect semen quality? Epidemiology. 2003; 14:261-262. [PubMed: 12859024]

6. Aneck-Hahn NH, Schulenburg GW, Bornman MS, Farias P, de Jager C. Impaired semen quality associated with environmental DDT exposure in young men living in a malaria area in the Limpopo Province, South Africa. J Androl. 2007; 28:423-434. [PubMed: 17192596]

7. De Jager C, Farias P, Barraza-Villarreal A, Avila MH, Ayotte P, Dewailly E, Dombrowski C, Rousseau F, Sanchez VD, Bailey JL. Reduced seminal parameters associated with environmental DDT exposure and p,p'-DDE concentrations in men in Chiapas, Mexico: a cross-sectional study. J Androl. 2006; 27:16-27. [PubMed: 16400073] 
8. Bonde JP, Toft G, Rylander L, Rignell-Hydbom A, Giwercman A, Spano M, Manicardi GC, Bizzaro D, Ludwicki JK, Zvyezday V, Bonefeld-Jørgensen EC, Pedersen HS, Jönsson BA, Thulstrup AM. INUENDO, Fertility and markers of male reproductive function in Inuit and European populations spanning large contrasts in blood levels of persistent organochlorines. Environ Health Perspect. 2008; 116:269-277. [PubMed: 18335090]

9. Joensen UN, Bossi R, Leffers H, Jensen AA, Skakkebaek NE, Jørgensen N. Do perfluoroalkyl compounds impair human semen quality? Environ Health Perspect. 2009; 117:923-927. [PubMed: 19590684]

10. Meeker JD, Barr DB, Hauser R. Human semen quality and sperm DNA damage in relation to urinary metabolites of pyrethroid insecticides. Hum Reprod. 2008:1932-1940. [PubMed: 18579513]

11. Rubes J, Selevan SG, Evenson DP, Zudova D, Vozdova M, Zudova Z, Robbins WA, Perreault SD. Episodic air pollution is associated with increased DNA fragmentation in human sperm without other changes in semen quality. Hum Reprod. 2005:2776-2783. [PubMed: 15980006]

12. Storgaard LL, Bonde JP, Ernst EE, Andersen CY, Spana MM, Christensen KK, Petersen HC, Olsen J. Genetic and environmental correlates of semen quality: a twin study. Epidemiology. 2006:674-81. [PubMed: 17003685]

13. Hauser R, Meeker JD, Duty S, Silva MJ, Calafat AM. Altered semen quality in relation to urinary concentrations of phthalate monoester and oxidative metabolites. Epidemiology. 2006:682-691. [PubMed: 17003688]

14. Luben TJ, Olshan AF, Herring AH, Jeffay S, Strader L, Buus RM, Chan RL, Savitz DA, Singer PC, Weinberg HS, Perreault SD. The Healthy Men Study: An Evlauation of Exposure to Disinfection By-Products in Tap Water and Sperm Quality. Environ Health Perspect. 2007; 115:1169-1176. [PubMed: 17687443]

15. Pegram RA, Andersen ME, Warren SH, Ross TM, Claxton LD. Glutathione S-Transferasemediated mutagenicity of thrihalomethanes in Salmonella typhimurium: contrasting results with bromodichloromethane and chloroform. Toxicol Appl Pharmacol. 1997; 144:183-188. [PubMed: 9169083]

16. Zhang H, Ahmadi A, Arbman G, Zdolsek J, Carstensen J, Nordenskjold B, Soderkvist P, Sun XF. Glutathione S-transferase T1 and M1 genotypes in normal mucosa, transitional mucosa and colorectal adenocarcinoma. Int J Cancer. 1999; 84:135-138. [PubMed: 10096244]

17. Pemble S, Schroeder KR, Spencer SR, Meyer DJ, Hallier E, Bolt HM, Ketterer B. Human glutathione S-transferase theta (GSTT1): cDNA cloning and the characterization of a genetic polymorphism. Biochem J. 1994; 300:271-276. [PubMed: 8198545]

18. Seidegard J, Pero RW. The genetic variation and the expression of human glutathione transferase mu. Klinische Wochenshrift. 1988; 66:25-26.

19. Egan KM, Cai Q, Shu XO, Jin F, Zhu TL, Dai Q, Gao YT, Zheng W. Genetic polymorphisms in GSTM1, GSTP1 and GSTT1 and the risk for breast cancer: results from the Shanghai Breast Cancer Study and meta-analysis. Cancer Epidemiol Biomarkers Prev. 2004; 13:197-204. [PubMed: 14973092]

20. Wang LS, Tang JJ, Tang NP, Wang MW, Yan JJ, Wang QM, Yang ZJ, Wang B. Association of GSTM1 and GSTT1 gene polymorphisms with coronary artery disease in relation to tobacco smoking. Clin Chem Lab Med. 2008; 46:1720-1725. [PubMed: 19055448]

21. Grazuleviciene R, Danilviciute A, Nadisauskiene R, Vencloviene J. Maternal smoking, GSTM1 and GSTT1 polymorphism and susceptibility to adverse pregnancy outcomes. Int J Environ Res Public Health. 2009; 6:1282-1297. [PubMed: 19440446]

22. Paracchini V, Chang SS, Santella RM, Garte S, Pedotti P, Taioli E. GSTM1 deletion modifies the levels of polycyclic aromatic hydrocarbon-DNA adducts in human sperm. Mutat Res. 2005; 586:97-101. [PubMed: 16105747]

23. Aydemir B, Onaran I, Kiziler AR, Alici B, Akyolcu MC. Increased oxidative damage of sperm and seminal plasma in men with idiopathic infertility is higher in patients with glutathione Stransferase Mu-1 null genotype. Asian J Androl. 2007; 9:108-115. [PubMed: 17187162] 
24. Aydos SE, Taspinar M, Sunguroglu A, Aydos K. Association of CYP1A1 and glutathione Stransferase polymorphisms with male factor infertility. Fertil Steril. 2009; 92:541-547. [PubMed: 18774560]

25. Board PG, Anders MW. Human glutathione transferase zeta. Methods Enzymol. 2005; 401:61-77. [PubMed: 16399379]

26. Blackburn AC, Coggan M, Tzeng HF, Lantum H, Polekhina G, Parker MW, Anders MW, Board PG. GSTZ1d: a new allele of glutathione transferase zeta and maleylacetoacetate isomerase. Pharmacogenetics. 2001; 11:671-678. [PubMed: 11692075]

27. Blackburn AC, Tzeng HF, Anders MW, Board PG. Discovery of a functional polymorphism in human glutathione transferase zeta by expressed sequence tag database analysis. Pharmacogenetics. 2000; 10:49-57. [PubMed: 10739172]

28. Fang YY, Kashkarov U, Anders MW, Board PG. Polymorphisms in the human glutathione transferase zeta promoter. Pharmacogenet Genomics. 2006; 16:307-313. [PubMed: 16609361]

29. Olshan AF, Perreault SD, Bradley L, Buus RM, Strader LF, Jeffay SC, Lansdell L, Savitz DA, Herring A. The healthy men study: design and recruitment considerations for environmental epidemiologic studies in male reproductive health. Fertil Steril. 2007; 87:554-564. [PubMed: 17140573]

30. Savitz, DA.; Singer, PC.; Hartmann, KE.; Herring, AH.; Weinberg, HS.; Makarushka, C., et al. Drinking Water Disinfection By-Products and Pregnancy Outcome. American Water Works Association; Denver, Co: 2005. p. 212

31. Savitz DA, Singer PC, Herring AH, Hartmann KE, Weinberg HS, Makarushka C. Drinking water disinfection by-product exposure and pregnancy loss. Am J Epidemiol. 2006; 164:1043-1051. [PubMed: 16957027]

32. Royster MO, Lobdell DT, Mendola P, Perreault SD, Selevan SG, Rothmann SA, Robbins WA. Evaluation of a container for collection and shipment of semen with potential uses in populationbased, clinical, and occupational settings. J Androl. 2000; 21:478-484. [PubMed: 10819457]

33. Zinaman MJ, Uhler ML, Vertuno E, Fisher SG, Clegg ED. Evaluation of computer-assisted semen analysis (CASA) with IDENT stain to determine sperm concentration. J Androl. 1996; 17:288292. [PubMed: 8792219]

34. World Health Organization. WHO Laboratory Manual for the Examination of Human Semen and Semen-Cervical Mucus Interactions. 4. Cambridge University Press; Cambridge, UK: 1999.

35. Evenson P, Jost L. Sperm chromatin structure assay is useful for fertility assessment. Methods Cell Sci. 2000; 22:169-80. [PubMed: 11264952]

36. Sakkas D, Manicardi G, Bianchi PG, Bizzaro D, Bianchi U. Relationship between the presence of endogenous nicks and sperm chromatin packaging in maturing and fertilizing mouse spermatozoa. Biol Reprod. 1995; 52:1149-1155. [PubMed: 7626715]

37. Bell, D.; Pittman, G. Genotype analysis. In: Vanden Heuvel, LP., editor. PCR Protocols in Molecular Toxicology. CRC Press; Boca Raton, FL: 1998. p. 163-176.

38. Millikan R, Pittman G, Tse CK, Savitz DA, Newman B, Bell D. Glutathione S-transferases M1, T1, and P1 and breast cancer. Cancer Epidemiol Biomarkers Prev. 2000; 9:567-573. [PubMed: 10868690]

39. Meister A, Anderson ME. Glutathione. Annu Rev Biochem. 1983; 52:711-760. [PubMed: 6137189]

40. Listowsky I. Proposed intracellular regulatory functions of glutathione transferases by recognition and binding to S-glutathiolated proteins. J Pept Res. 2005; 65:42-46. [PubMed: 15686533]

41. Mukherjee SB, Aravinda S, Gopalakrishnan B, Nagpal S, Salunke DM, Shaha C. Secretion of glutathione S-transferase isoforms in the seminiferous tubular fluid, tissue distribution and sex steroid binding by rat GSTM1. Biochem J. 1999; 340:309-320. [PubMed: 10229687]

42. Hemachand T, Gopalakrishnan B, Salunke DM, Totey SM, Shaha C. Sperm plasma-membraneassociated glutathione S-transferases as gamete recognition molecules. J Cell Sci. 2002; 115:2053-2065. [PubMed: 11973347]

43. Talalay P, Fahey JW, Holtzclaw WD, Prestera T, Zhang Y. Chemoprotection against cancer by phase 2 enzyme induction. Toxicol Lett. 1995; 82-83:173-179. 
44. Wilkinson J, Clapper ML. Detoxication enzymes and chemoprevention. Proc Soc Exp Biol Med. 1997; 216:192-200. [PubMed: 9349688]

45. Turner TT, Lysiak JL. Oxidative stress: a common factor in testicular function. J Andol. 2008; 29:488-498.

46. Agarwal A, Makker K, Sharma R. Clinical relevance of oxidative stress in male factor infertility: an update. Am J Reprod Immunol. 2008; 5:2-11. [PubMed: 18154591]

47. Aitken RJ, De Iuliis GN, McLachlan RI. Biological and clinical significance of DNA damage in the male germ line. Int J Androl. 2009; 32:46-56. [PubMed: 19076252]

48. Chen SS, Chang LS, Chen HW, Wei YH. Polymorphisms of glutathione S-transferase M1 and male infertility in Taiwanese patients with varicocele. Hum Reprod. 2002; 17:718-725. [PubMed: 11870126]

49. Okubo K, Nagahama K, Kamoto T, Okuno H, Ogawa O, Nishiyama H. GSTT1 and GSTM1 polymorphisms are associated with improvement in seminal findings after varicocelectomy. Fertil Steril. 2005; 83:1579-1580. [PubMed: 15866612]

50. Messaros BM, Rossano MG, Liu G, Diamond MP, Friderici K, Nummy-Jernigan K, Daly D, Puscheck E, Paneth N, Wirth JJ. Negative effects of serum p,p'-DDE on sperm parameters and modification by genetic polymorphisms. Environ Res. 2009; 109:457-464. [PubMed: 19303595]

51. Selevan SG, Borkovec L, Slott VL, Zudová Z, Rubes J, Evenson DP, Perreault SD. Semen quality and reproductive health of young Czech men exposed to seasonal air pollution. Environ Health Perspect. 2000; 108:887-894. [PubMed: 11017895]

52. Rubes J, Selevan SG, Sram RJ, Evenson DP, Perreault SD. GSTM1 genotype influences the susceptibility of men to sperm DNA damage associated with exposure to air pollution. Mutat Res. 2007; 625:20-28. [PubMed: 17714740] 
Table 1

Selected sociodemographic characteristics for HMS cohorts (based on maternal interview data).

\begin{tabular}{|c|c|c|c|}
\hline & $\begin{array}{l}\text { HMS eligible men }(\mathbf{n}=274) \\
n(\%)\end{array}$ & $\begin{array}{c}\text { HMS final }(\mathbf{n}=228) \\
\text { n }(\%)\end{array}$ & $\begin{array}{c}\text { HMS genetic analysis }(\mathrm{n}=162) \\
\mathrm{n}(\%)\end{array}$ \\
\hline \multicolumn{4}{|l|}{ Site } \\
\hline Memphis, TN & $109(39.8)$ & $91(39.9)$ & $69(42.6)$ \\
\hline Raleigh, NC & $106(38.7)$ & $92(40.4)$ & $67(41.4)$ \\
\hline Galveston, TX & $59(21.5)$ & 45 (19.7) & $26(16.0)$ \\
\hline \multicolumn{4}{|l|}{ Race/ethnicity ${ }^{a}$} \\
\hline White, Non-Hispanic & $210(77.2)$ & $187(82.0)$ & $146(90.1)$ \\
\hline Black, Non-Hispanic & $32(11.8)$ & $18(7.9)$ & $15(9.3)$ \\
\hline Hispanic & $6(2.2)$ & $0(0.0)$ & $0(0.0)$ \\
\hline Asian & $3(1.1)$ & $3(1.3)$ & $0(0.0)$ \\
\hline Other & $21(7.7)$ & $17(7.5)$ & $1(0.6)$ \\
\hline \multicolumn{4}{|l|}{ Paternal age } \\
\hline$<25$ & $38(14.0)$ & $26(11.4)$ & $15(9.3)$ \\
\hline $25-29$ & $84(30.9)$ & $71(31.1)$ & $46(28.4)$ \\
\hline $30-34$ & $102(37.5)$ & $89(39.0)$ & $71(43.8)$ \\
\hline$>=35$ & $48(17.7)$ & $42(18.4)$ & $30(18.5)$ \\
\hline \multicolumn{4}{|l|}{ Paternal education } \\
\hline$<=$ High school & $56(20.7)$ & $37(16.3)$ & $18(11.1)$ \\
\hline Some college & $54(20.0)$ & $42(18.5)$ & $30(18.5)$ \\
\hline College graduate + some graduate work & $160(59.3)$ & $148(65.2)$ & $114(70.4)$ \\
\hline \multicolumn{4}{|l|}{ Household income } \\
\hline$<=20,000 /$ year & $28(10.4)$ & $19(8.4)$ & $7(4.3)$ \\
\hline $20,001-40,000 /$ year & $59(21.9)$ & $43(19.1)$ & $22(13.6)$ \\
\hline $40,001-80,000 /$ year & $125(46.5)$ & $111(49.3)$ & $82(50.6)$ \\
\hline$>=80,0001 /$ year & $57(21.2)$ & $52(23.1)$ & $48(30.2)$ \\
\hline \multicolumn{4}{|l|}{ Smoke Cigarettes } \\
\hline No & 164(59.9) & $136(59.6)$ & $106(65.4)$ \\
\hline Yes & $110(40.1)$ & $92(40.4)$ & $56(34.6)$ \\
\hline
\end{tabular}

${ }^{a}$ Race/ethnicity for the eligible men (first column) was obtained from the interview with the women. For the final interview, semen and genetic analyses (columns 2 and 3), this information was obtained from the male interview. 


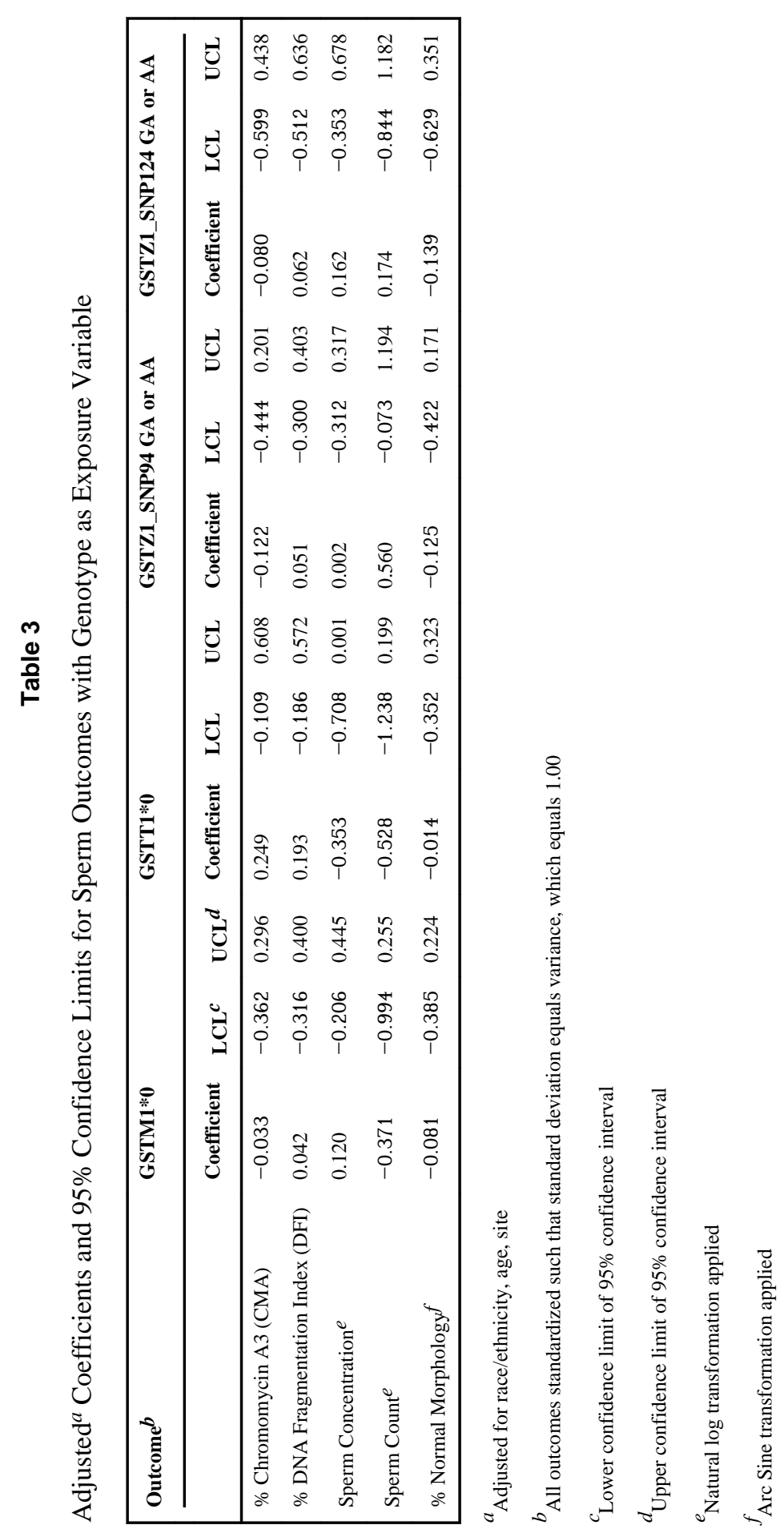

Mutat Res. Author manuscript; available in PMC 2012 April 8. 